\title{
Prognostic and diagnostic role of PSA immunohistochemistry: A tissue microarray study on 21,000 normal and cancerous tissues
}

\author{
Sarah Bonk ${ }^{2}$, Martina Kluth ${ }^{1}$, Claudia Hube-Magg ${ }^{1}$, Adam Polonski², Greta \\ Soekeland ${ }^{1}$, Georgia Makropidi-Fraune ${ }^{1}$, Christina Möller-Koop ${ }^{1}$, Melanie Witt ${ }^{1}$, \\ Andreas M. Luebke ${ }^{1}$, Andrea Hinsch ${ }^{1}$, Eike Burandt ${ }^{1}$, Stefan Steurer ${ }^{1}$, Till $\mathbf{S}$. \\ Clauditz $^{1}$, Thorsten Schlomm ${ }^{3}$, Daniel Perez ${ }^{2}$, Markus Graefen ${ }^{4}$, Hans Heinzer ${ }^{4}$, \\ Hartwig Huland4, Jakob R. Izbicki ${ }^{2}$, Waldemar Wilczak ${ }^{1}$, Sarah Minner ${ }^{1}$, Guido \\ Sauter ${ }^{1}$ and Ronald Simon ${ }^{1}$ \\ ${ }^{1}$ Institute of Pathology, University Medical Center Hamburg-Eppendorf, Hamburg, Germany \\ ${ }^{2}$ General, Visceral and Thoracic Surgery Department, University Medical Center Hamburg-Eppendorf, Hamburg, Germany \\ ${ }^{3}$ Urology Clinic, Charite - Universitätsmedizin Berlin, Berlin, Germany \\ ${ }^{4}$ Martini Clinic, University Medical Center Hamburg-Eppendorf, Hamburg, Germany \\ Correspondence to: Ronald Simon, email: r.simon@uke.de \\ Keywords: prostate specific antigen; specificity; immunohistochemistry; prognosis marker; tissue microarray \\ Received: May 07, $2019 \quad$ Accepted: July 17, $2019 \quad$ Published: September 10, 2019 \\ Copyright: Bonk et al. This is an open-access article distributed under the terms of the Creative Commons Attribution License 3.0 \\ (CC BY 3.0), which permits unrestricted use, distribution, and reproduction in any medium, provided the original author and source \\ are credited.
}

\section{ABSTRACT}

To assess the prognostic and diagnostic utility of PSA immunostaining, tissue microarrays containing 17,747 prostate cancers, 3,442 other tumors from 82 different (sub) types and 608 normal tissues were analyzed at two different antibody concentrations (1:100 and 1:800). In normal tissues, PSA expression was limited to prostate epithelial cells. In prostate cancers, PSA staining was seen in 99.9-100\% (1:800-1:100) primary tumors, 98.7-99.7\% of advanced recurrent cancers, in 84.691.4\% castration resistant cancers, and in 7.7-18.8\% of 16 small cell carcinomas. Among extraprostatic tumors, PSA stained positive in 0-3 (1:800-1:100) of 19 osteosarcomas, 1-2 of 34 ovarian cancers, 0-2 of 35 malignant mesotheliomas, 0-1 of 21 thyroid gland carcinomas and 0-1 of 26 large cell lung cancers. Reduced staining intensity and loss of apical staining were strongly linked to unfavorable tumor phenotype and poor prognosis $(p<0.0001$ each). This was all the more the case if a combined "PSA pattern score" was built from staining intensity and pattern. The prognostic impact of the "PSA pattern score" was independent of established pre- and postoperative clinico-pathological prognostic features. In conclusion, PSA immunostaining is a strong prognostic parameter in prostate cancer and has high specificity for prostate cancer at a wide range of antibody dilutions.

\section{INTRODUCTION}

Prostate cancer $(\mathrm{PCa})$ is the most common cancer in men. More than $70 \%$ of men at the age of 75 carry one or several cancers in their prostate. Most of these tumors remain undetected and will not generate symptoms throughout the life of affected men. However, more than 170,000 prostate cancers are annually detected in the United States and 30,000 patients die from their disease
[1]. This makes prostate cancer the most commonly diagnosed cancer and the second most common cause of tumor associated death in males.

Prostate specific antigen (PSA) is the most relevant protein for the management of men with suspected or diagnosed prostate cancer. The protease PSA is exclusively produced in prostate epithelial cells [2]. It is secreted to the seminal fluid and plays a role for its liquefaction [3]. Only minor quantities of PSA reach the blood stream. 
The serum PSA level is largely proportionate to the quantity of prostate epithelial cells in the body [4]. An increased serum PSA level is the most common cause for prostate cancer suspicion and subsequent prostate biopsy. In men with diagnosed prostate cancer, serum PSA analysis is the most commonly used parameter to monitor disease recurrence and response to therapy.

PSA analysis is also common in pathology. Due to its perceived prostate specificity, immunohistochemical PSA analysis is routinely used to determine whether tumor bulks of unknown origin can be assigned to a prostate cancer. However, cellular PSA expression can be substantially reduced in poorly differentiated prostate cancers, which can result in PSA negative immunohistochemistry and widespread metastatic prostate cancers with very low serum PSA levels [5, 6]. It is thus not surprising that studies on cohorts of 40-2,556 prostate cancers had earlier suggested associations with unfavorable tumor features or even a prognostic role of reduced PSA levels [7-10].

Although PSA immunohistochemistry is commonly used in routine histopathological diagnosis, several issues are not satisfactorily clarified. These include: 1 . Is PSA expression indeed prostate cancer specific or can PSA be (ectopically) expressed in other cancers? 2. Has the immunohistochemically determined PSA level of a cancer a prognostic impact that is substantial enough to be potentially clinically useful, and 3 . To what extent is the diagnostic and prognostic role of PSA immunohistochemistry dependent on the selected experimental procedure (antibody concentration)? To answer these questions, more than 20,000 prostate cancers (including hormonally treated, castration refractory, and small cell carcinomas) as well as 3,442 other malignant and benign tumors were analyzed for PSA expression utilizing two different antibody concentrations.

\section{RESULTS}

\section{Prognostic role of PSA expression in prostate cancer.}

$64 \%$ and $62 \%$ of the 17,747 tumor samples were interpretable in our TMA analysis utilizing different (1:800 and 1:100) antibody concentrations. Reason for non-informative cases included lack of tissue samples or absence of unequivocal cancer tissue in the TMA spot. In normal prostate glands, PSA immunostaining typically showed a conspicuous predominance at the apical portion of the cells. Apical predominance was also retained in a fraction of cancers. Examples of PSA immunostainings in prostate tissues are given in Figure 1. Reduced PSA levels were associated with TMPRSS2: ERG fusions and PTEN deletions. Both reduced staining intensity and a loss of apical predominance (apical loss) of PSA staining were strikingly linked to unfavorable tumor phenotype and prognosis. This also hold true for subsets of ERG positive, ERG negative and PTEN deleted cancers. The respective data are shown for the 1: 800 dilution in Supplementary Table 1 and Figures 2 and 3. The combined analysis of PSA staining pattern and intensity demonstrated that the outcome of cancers with apical staining loss was comparable to cancers having a "one level lower" intensity score (Figure 4). Accordingly, tumors with moderate staining intensity and apical staining loss were considered "weak" and tumors with weak staining intensity and apical staining loss were considered "negative" in a separate analysis. Tumors with moderate to strong staining were combined into one group "strong". The prognostic impact of this "PSA pattern score" was statistically independent of established prognostic parameters (Table 1). If the PSA antibody was diluted 1:100, the fraction of completely "PSA negative" cases decreased from $0.2 \%$ (antibody dilution $1: 800$ ) to $0.07 \%$ and the fraction of tumors with "strong PSA positivity" increased from 40\% (at 1: 800) to $81 \%$. Irrespective of the changes in the number of cancers classified as PSA "negative", "weak", "moderate" and "strong", striking and statistically independent statistical associations with tumor phenotype and patient outcome were similarly visible for pattern and intensity of PSA staining at 1: 100 (Supplementary Table 2 and Supplementary Figure 1).

\section{Diagnostic role of PSA immunostaining}

To evaluate the sensitivity and specificity of PSA immunostaining for diagnosing prostate cancer, 12,824 prostate cancers and 2,845 tumors from other origins were evaluated at two antibody concentrations. The data from various categories of prostate cancer, and of all tumor types showing occasional PSA immunostaining are shown in Table 2. At 1:800, 99.9\% of Gleason $\leq 3+4$ show detectable PSA immunostaining. The fraction of "PSA negative" cancers increased with cancer dedifferentiation but even in case of castration refractory cancers, the rate of positivity was still $>80 \%$. However, only 1 of 13 small cell neuroendocrine carcinomas of the prostate showed PSA expression. In all these prostate cancers, the use of an eightfold higher antibody concentration increased the positivity rate. This increase was only marginally in case of Gleason $\leq 3+4$ cancers but more significant in dedifferentiated cancers. PSA immunostaining was not completely specific for tumors of the prostate. However, only one extraprostatic cancer, i. e., an endometroid cancer of the ovary, showed detectable PSA staining at 1:800 (Figure 5A). At 1:100, PSA positivity was seen in additional 8 (total: 9 of 2,845, $0.3 \%$ ) interpretable extraprostatic cancers, including another ovarian cancer, 3 osteosarcomas, 2 malignant mesotheliomas, and one case each of thyroid gland cancer and large cell lung cancer (Figure 5B-5E). A list of PSA negative cancers is given in 
Table 3. Examples of PSA immunostainings are shown in Supplementary Figure 2. All eight normal prostatic tissues were PSA positive while PSA staining was absent in all other analyzed normal tissues including mesenchymal tissues (aorta/intima, aorta/media, heart (left ventricle), skeletal muscle, sceletal muscle/tongue, myometrium, appendix (muscular wall), esophagus (muscular wall), stomach (muscular wall), ileum (muscular wall), colon descendens (muscular wall), kidney pelvis (muscular wall), urinary bladder (muscular wall), penis (glans/ corpus spongiosum), ovary (stroma), fat tissue (white)), surfaces (skin (surface), skin (hairs, sebaceous glands), lip (epithelium), oral cavity, tonsil (surface epithelium), anal canal (skin), anal canal (transition epithelium), exocervix, esophagus, kidney pelvis, urinary bladder, amnion/chorion, stomach (antrum), stomach (fundus and corpus), small intestine, duodenum, small intestine, ileum, appendix, colon descendens, rectum, gallbladder, bronchus, paranasal sinus) and solid organs (lymph node, spleen, thymus, tonsil, liver, pancreas, parotid gland, submandibular gland, sublingual gland, lip (small salivary gland), duodenum (Brunner gland), kidney cortex, kidney medulla, prostate, seminal vesicle, epididymis, testis, lung (parenchyma), lung (bronchial glands), breast, endocervix,
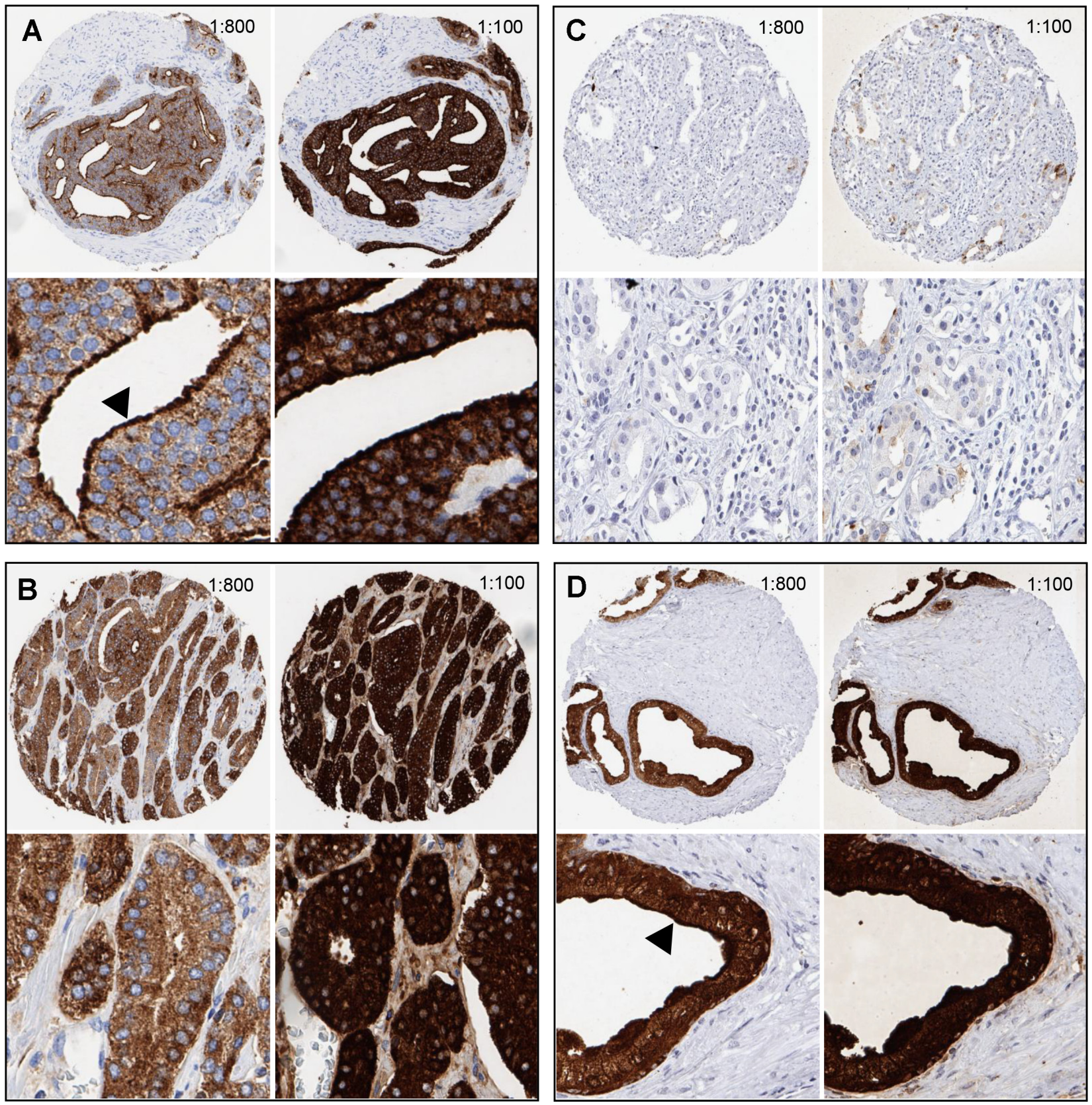

Figure 1: Examples of PSA immunostaining at two different antibody dilutions (1:100, 1:800) in prostate tissues. (A) Prostate cancer with apical staining (arrowhead). (B) Absence of apical staining. (C) PSA-negative prostate cancer. (D) Normal prostate glands showing apical staining (arrowhead). 


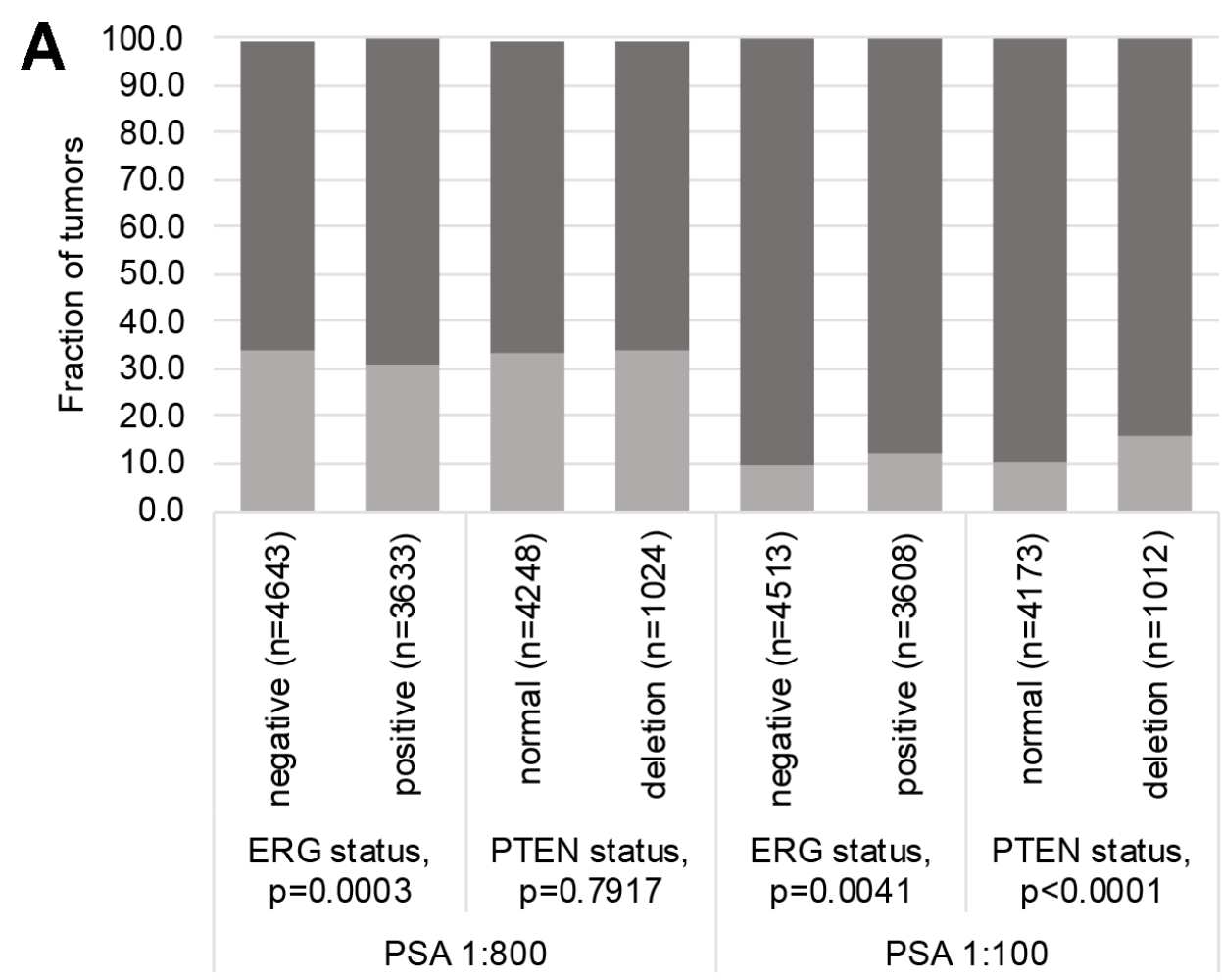

Apical predominance absent (\%) $\quad$ Apical predominance present (\%)

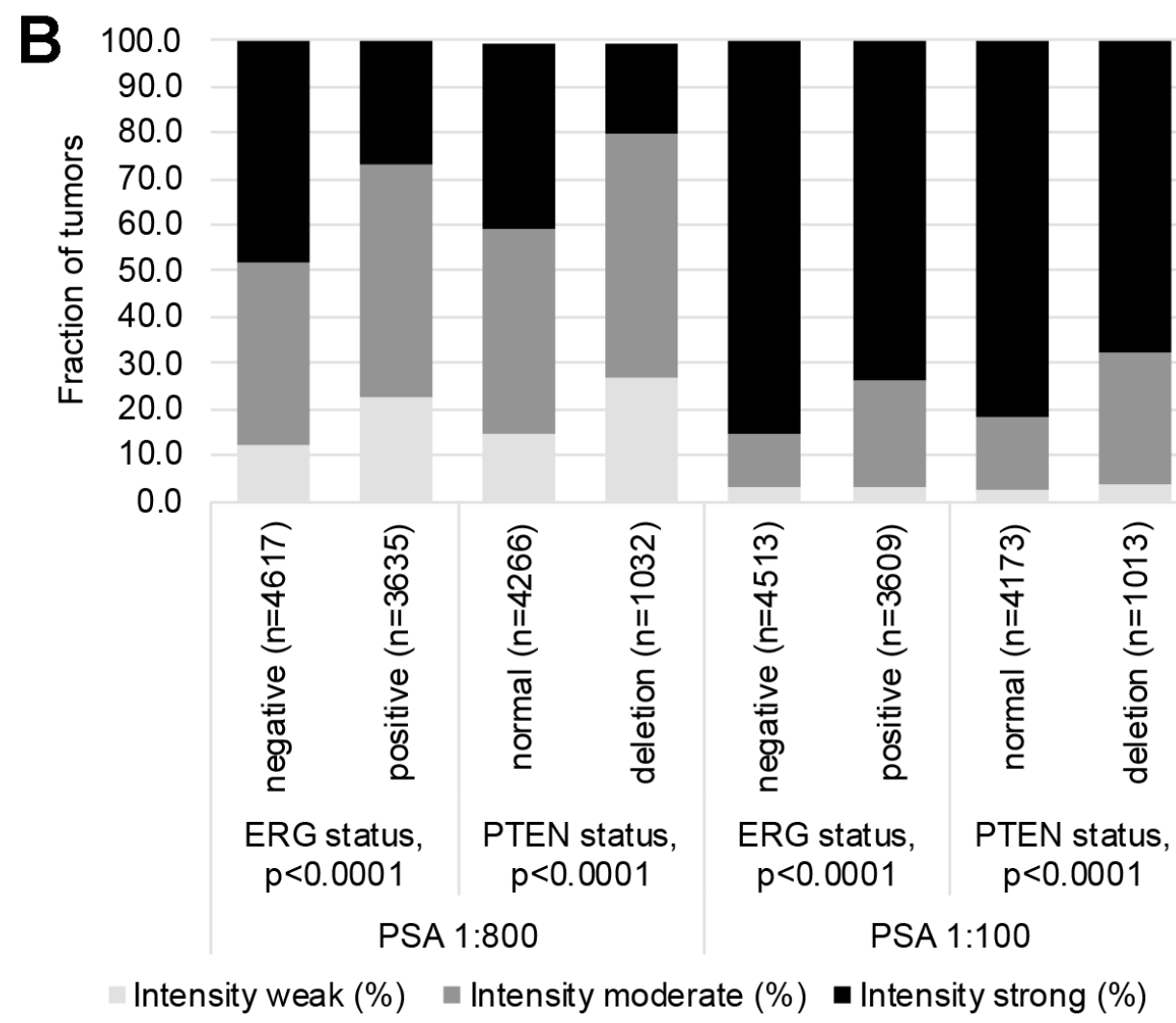

Figure 2: Associations between PSA immunostaining results (using the anti PSA antibody at 1:100 and 1:800 dilution), TMPRSS2: ERG fusion status and PTEN deletion status. (A) PSA immunostaining scored for presence or absence of apical predominance. (B) PSA immunostaining scored for the staining intensity. 

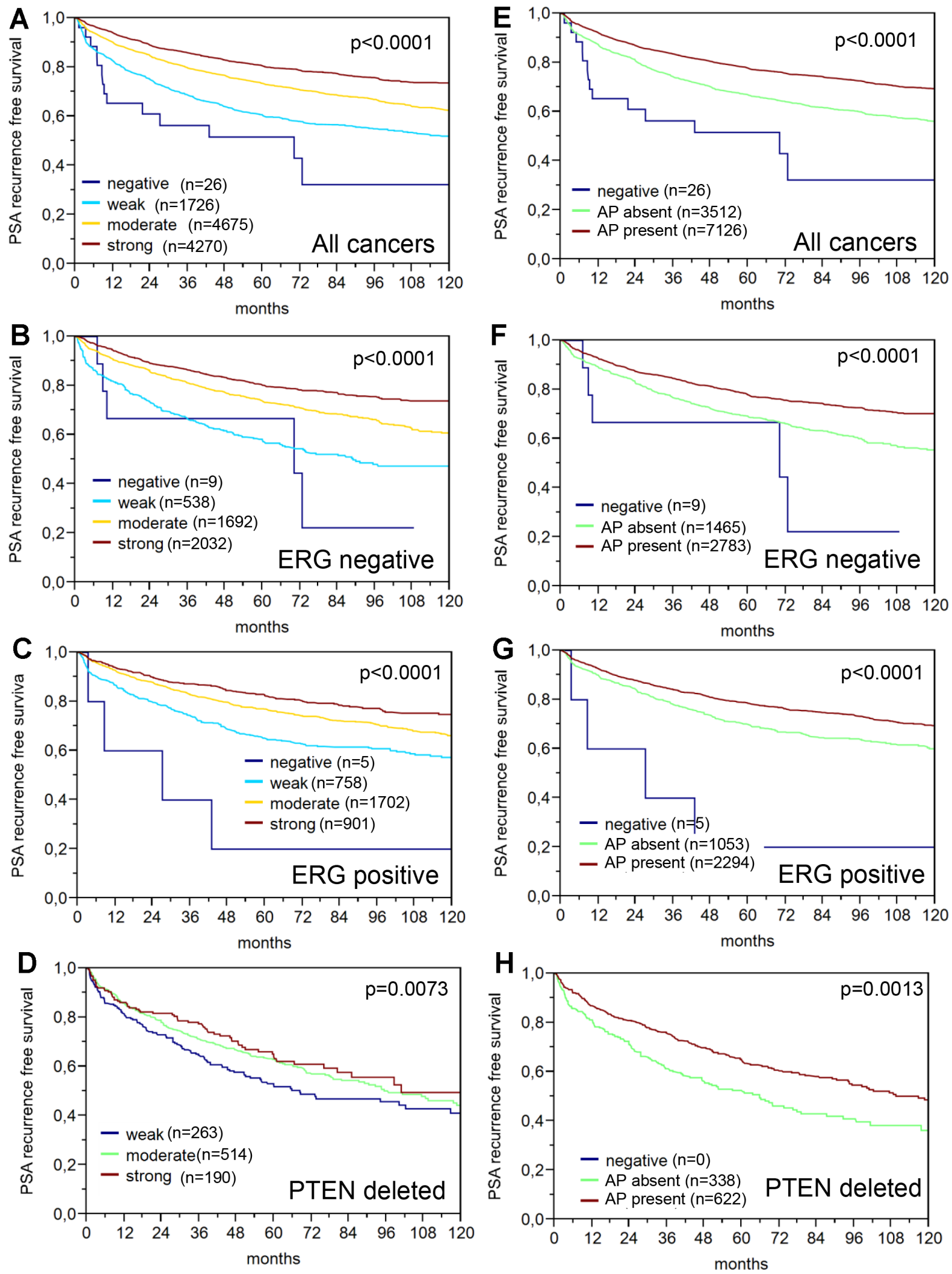

Figure 3: Prognostic relevance of PSA immunostaining (dilution 1:800) in prostate cancer. (A-D) Impact of the PSA staining intensity in (A) all cancers, (B) TMPRSS2: ERG, (C) TMPRSS2: ERG positive and (D) PTEN deleted cancers. (E-H) Impact of the presence or absence of apical predominance (AP) of the PSA staining in (E) all cancers, (F) TMPRSS2: ERG negative, (G) TMPRSS2: ERG positive and (H) PTEN deleted cancers. 

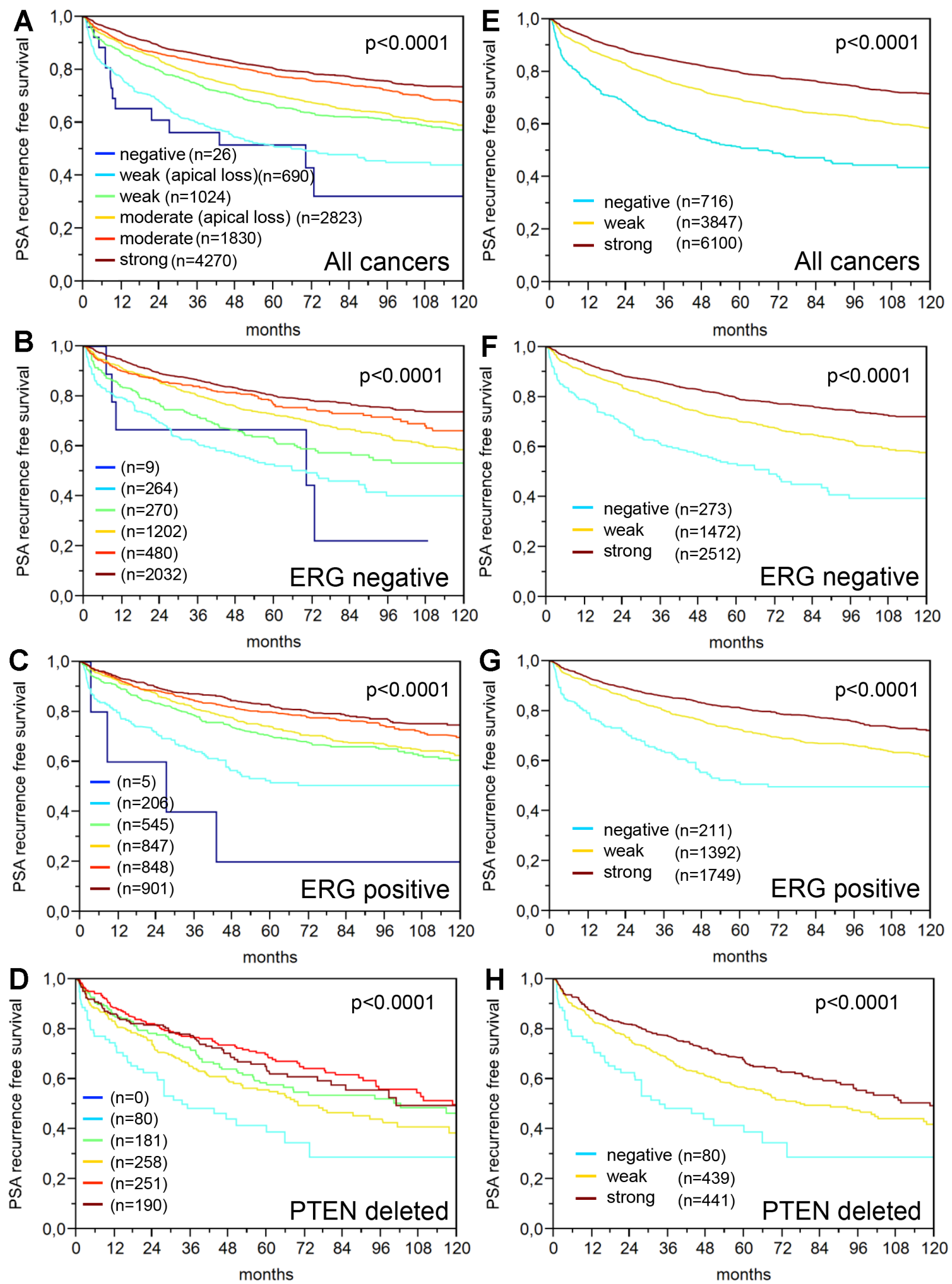

Figure 4: Prognostic relevance of the PSA staining in prostate cancer. (A-D) Combination of the PSA staining intensity and apical predominance in (A) all cancers, (B) TMPRSS2: ERG negative cancers, (C) TMPRSS2: ERG positive cancers and (D) PTEN deleted cancers. (E-H) Prognostic impact of the "PSA pattern score" in (E) all cancers, (F) TMPRSS2: ERG negative, (G) TMPRSS2: ERG positive and (H) PTEN deleted cancers. 
Table 1: Multivariat analysis including established prognostic parameters and the "PSA pattern score" (PSA score)

\begin{tabular}{|c|c|c|c|c|c|c|c|c|c|c|}
\hline \multirow{2}{*}{$\begin{array}{l}\text { Tumor } \\
\text { subset }\end{array}$} & \multirow{2}{*}{ Scenario } & & \multicolumn{8}{|c|}{$p$-value } \\
\hline & & n analyzable & $\begin{array}{c}\text { preoperative } \\
\text { PSA-Level }\end{array}$ & pT Stage & cT Stage & $\begin{array}{l}\text { Gleason grade } \\
\text { prostatectomy }\end{array}$ & $\begin{array}{c}\text { Gleason } \\
\text { grade biopsy }\end{array}$ & pN Stage & R Stage & PSA score \\
\hline \multirow{4}{*}{$\begin{array}{l}\text { all } \\
\text { cancers }\end{array}$} & 1 & 6,923 & $<0.0001$ & $<0.0001$ & - & $<0.0001$ & - & $<0.0001$ & $<0.0001$ & $<0.0001$ \\
\hline & 2 & 10,552 & $<0.0001$ & $<0.0001$ & - & $<0.0001$ & - & - & $<0.0001$ & $<0.0001$ \\
\hline & 3 & 10,392 & $<0.0001$ & - & $<0.0001$ & $<0.0001$ & - & - & - & $<0.0001$ \\
\hline & 4 & 8,878 & $<0.0001$ & - & $<0.0001$ & - & $<0.0001$ & - & - & $<0.0001$ \\
\hline \multirow{4}{*}{$\begin{array}{l}\text { ERG- } \\
\text { negative } \\
\text { cancers }\end{array}$} & 1 & 2,723 & 0.0002 & $<0.0001$ & - & $<0.0001$ & - & 0.0008 & 0.0848 & $<0.0001$ \\
\hline & 2 & 4,245 & $<0.0001$ & $<0.0001$ & - & $<0.0001$ & - & - & 0.0033 & $<0.0001$ \\
\hline & 3 & 4,206 & $<0.0001$ & - & $<0.0001$ & $<0.0001$ & - & - & - & $<0.0001$ \\
\hline & 4 & 4,138 & $<0.0001$ & - & $<0.0001$ & - & $<0.0001$ & - & - & $<0.0001$ \\
\hline \multirow{4}{*}{$\begin{array}{l}\text { ERG- } \\
\text { positive } \\
\text { cancers }\end{array}$} & 1 & 2,134 & 0.0225 & $<0.0001$ & - & $<0.0001$ & - & 0.2417 & 0.0002 & 0.0226 \\
\hline & 2 & 3,339 & 0.0002 & $<0.0001$ & - & $<0.0001$ & - & - & $<0.0001$ & 0.0295 \\
\hline & 3 & 3,282 & $<0.0001$ & - & $<0.0001$ & $<0.0001$ & - & - & - & 0.0042 \\
\hline & 4 & 3,229 & $<0.0001$ & - & $<0.0001$ & - & $<0.0001$ & - & - & $<0.0001$ \\
\hline
\end{tabular}

For definition of the scenarios, see Statistics section.

Table 2: Sensitivity and specificity of DIA-PSA at 1:100 and 1:800 antibody dilution

\begin{tabular}{|c|c|c|c|c|}
\hline & \multicolumn{2}{|c|}{ Analyzable (n) } & \multicolumn{2}{|c|}{ PSA positive (\%) } \\
\hline & \multicolumn{2}{|c|}{ PSA antibody concentration } & \multicolumn{2}{|c|}{ PSA antibody concentration } \\
\hline & low $(1: 800)$ & high $(1: 100)$ & low $(1: 800)$ & high $(1: 100)$ \\
\hline \multicolumn{5}{|l|}{ Prostate cancers } \\
\hline Gleason $\leq 3+4$ & 9934 & 9672 & 99.89 & 99.96 \\
\hline Gleason $4+3$ & 2226 & 2190 & 99.64 & 99.95 \\
\hline Primary ca. $\geq 8$ & 233 & 216 & 98.71 & 99.07 \\
\hline Recurrent ca. $\geq 8$ & 392 & 383 & 98.72 & 99.74 \\
\hline CR ca., Gleason $\geq 8$ & 26 & 35 & 84.62 & 91.43 \\
\hline Small cell cancers & 13 & 16 & 7.69 & 18.75 \\
\hline Total & 12824 & 12512 & 99.66 & 99.81 \\
\hline \multicolumn{5}{|l|}{ Non-prostate cancers } \\
\hline Osteosarcoma & 19 & 19 & 0 & 15.79 \\
\hline Ovary, endometroid ca. & 30 & 34 & 3.33 & 5.88 \\
\hline Malignant Mesothelioma & 37 & 39 & 0 & 5.71 \\
\hline Thyroid gland, anaplastic ca. & 24 & 23 & 0 & 4.76 \\
\hline Lung, large cell ca. & 38 & 39 & 0 & 3.85 \\
\hline Other cancers types & 2697 & 2671 & 0 & 0 \\
\hline Total & 2845 & 2825 & 0.04 & 0.32 \\
\hline
\end{tabular}

endometrium (proliferation), endometrium (secretion), fallopian tube, endometrium (early decidua), ovary (stroma), ovary (corpus luteum), ovary (follicular cyst), placenta (first trimester), placenta (mature), adrenal gland, parathyroid gland, thyroid, cerebellum, cerebrum, pituitary gland (posterior lobe), pituitary gland (anterior lobe)).

\section{DISCUSSION}

The data from this study demonstrate that PSA measurement, apart from its known high sensitivity and specificity for prostatic epithelial tissue, provides striking prognostic information in prostate cancer patients.

The immunohistochemical analysis of protein expression is subject to inherent limitations. The staining intensity and its signal to noise ratio is markedly dependent from the type of reagents and the applied experimental protocols. Accordingly, literature data on the immunohistochemically detected expression are highly variable for most proteins that have been analyzed by different research groups $[17,18]$. The relatively small range, where protein expression can be quantitated in 

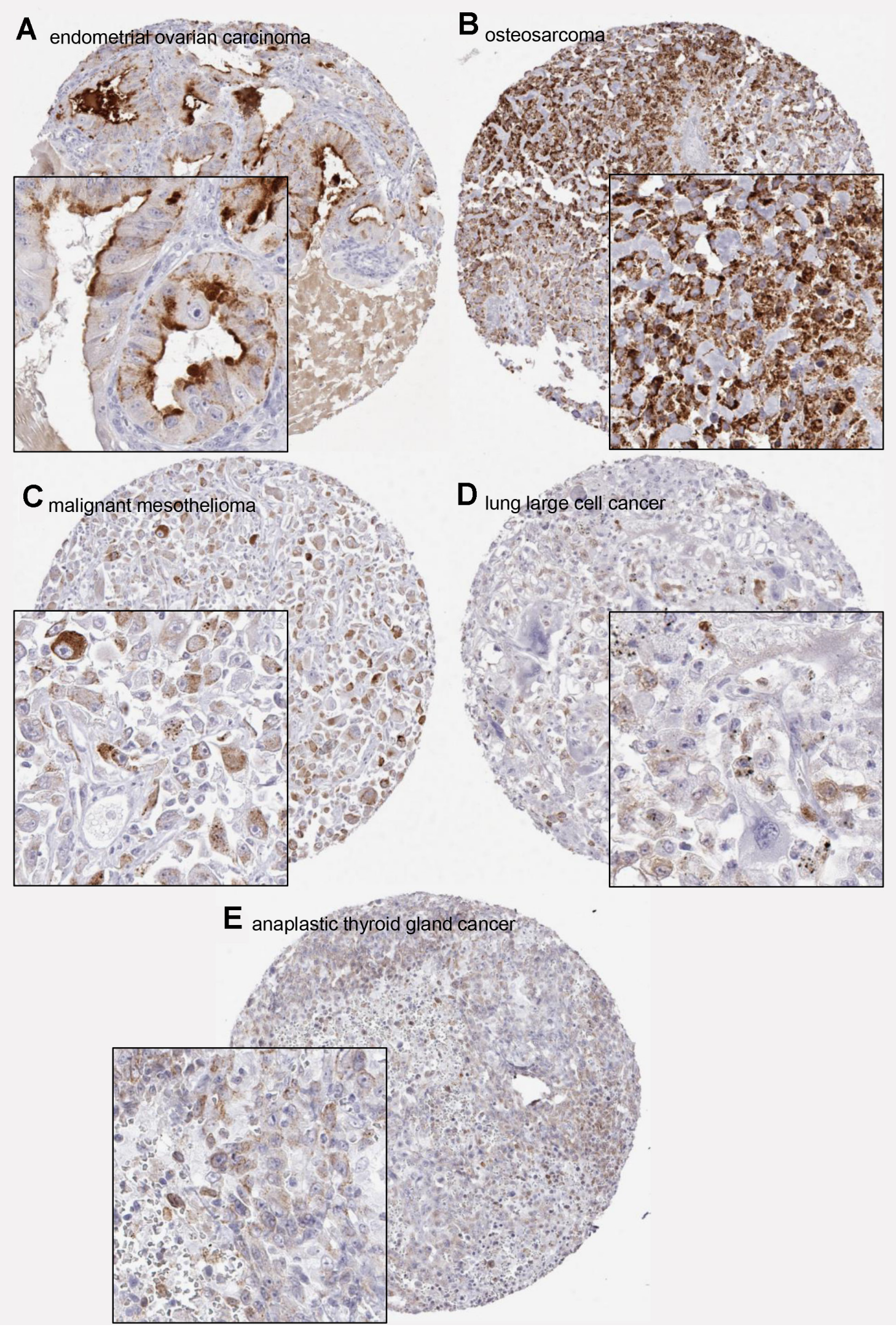

Figure 5: Examples of positive PSA immunostainings in non-prostatic tumors. (A) Anti-PSA antibody dilution 1:800, (B-E) antibody dilution 1:100. 
Table 3: Tumor types staining negative with DIA-PSA

\begin{tabular}{|c|c|c|c|}
\hline Organ system & Tumor type & $\overline{\text { n (on TMA) }}$ & n (analyzable) \\
\hline \multirow[t]{6}{*}{ Skin } & Pilomatrixoma & 35 & 23 \\
\hline & Basalioma & 48 & 44 \\
\hline & Benign naevus & 29 & 22 \\
\hline & Skin squamous cell cancer & 50 & 39 \\
\hline & Malignant melanoma & 48 & 44 \\
\hline & Merkel cell cancer & 46 & 46 \\
\hline \multirow[t]{9}{*}{ Respiratory tract } & Larynx squamous cell cancer & 50 & 32 \\
\hline & Oral cavity squamous cell cancer & 50 & 35 \\
\hline & Lung squamous cell cancer & 50 & 36 \\
\hline & Lung adenocarcinoma & 50 & 33 \\
\hline & Lung bronchioalveolary carcinoma & 6 & 5 \\
\hline & Lung small cell carcinoma & 13 & 16 \\
\hline & Salivary gland pleomorphic adenoma & 50 & 31 \\
\hline & Salivary gland Warthin tumor & 49 & 43 \\
\hline & Salivary gland basal cell adenoma & 15 & 12 \\
\hline \multirow[t]{17}{*}{ Femal genital tract } & Vagina squamous cell cancer & 48 & 45 \\
\hline & Vulva squamous cell cancer & 50 & 41 \\
\hline & Cervix squamous cell cancer & 50 & 49 \\
\hline & Cervix adenocarcinoma & 50 & 44 \\
\hline & Endometrial carcinoma serous & 50 & 46 \\
\hline & Uterine stroma sarcoma & 12 & 8 \\
\hline & Carcinosarcoma & 48 & 39 \\
\hline & Ovarian cancer endometroid & 37 & 34 \\
\hline & Ovarian cancer serous & 50 & 45 \\
\hline & Ovarian cancer mucinous & 26 & 21 \\
\hline & Brenner tumor & 9 & 7 \\
\hline & Breast cancer of no special type & 46 & 33 \\
\hline & Breast cancer lobulary & 43 & 34 \\
\hline & Breast cancer medullary & 15 & 13 \\
\hline & Breast cancer tubulary & 18 & 13 \\
\hline & Breast cancer muzinous & 22 & 15 \\
\hline & Breast cancer phylloid & 50 & 33 \\
\hline \multirow[t]{11}{*}{ Gastrointestinal tract } & Colon adenoma, low grade & 50 & 46 \\
\hline & Colon adenoma, high grade & 50 & 50 \\
\hline & Colon adenocarcinoma & 50 & 42 \\
\hline & Small intestine adenocarcinoma & 10 & 6 \\
\hline & Gastric cancer, diffuse & 50 & 33 \\
\hline & Gastric cancer, intestinal & 50 & 39 \\
\hline & Esophageal adenocarcinoma & 50 & 29 \\
\hline & Esophageal squamous cell cancer & 49 & 37 \\
\hline & Anal canal squamous cell cancer & 50 & 46 \\
\hline & Cholangiocellulary carcinoma & 50 & 45 \\
\hline & Hepatocellulary carcinoma & 50 & 50 \\
\hline
\end{tabular}




\begin{tabular}{|c|c|c|c|}
\hline & Pankreatic ductal adenocarcinoma & 50 & 32 \\
\hline & Pankreatoc papilla adenocarcinoma & 30 & 19 \\
\hline & Pankreatic neuroendocrine tumor & 49 & 46 \\
\hline & Gastrointestinal stroma tumor (GIST) & 50 & 46 \\
\hline \multirow[t]{13}{*}{ Male urogenital tract } & Urinary bladder cancer $\mathrm{pTa}$ & 50 & 31 \\
\hline & Urinary bladder cancer pT2-4 & 50 & 39 \\
\hline & Urinary bladder cancer small cell & 18 & 18 \\
\hline & Renal cell carcinoma clear cell & 50 & 40 \\
\hline & Renal cell carcinoma papillary & 50 & 35 \\
\hline & Renal cell carcinoma chromophobic & 50 & 42 \\
\hline & Oncocytoma & 50 & 38 \\
\hline & Prostata cancer & 49 & 47 \\
\hline & Prostata cancer small cell & 17 & 16 \\
\hline & Seminoma & 50 & 42 \\
\hline & Embryonal carcinoma (testis) & 50 & 35 \\
\hline & Yolk sack tumor & 50 & 33 \\
\hline & Teratoma & 50 & 22 \\
\hline \multirow[t]{8}{*}{ Endocrine system } & Thyroid adenoma & 50 & 47 \\
\hline & Thyroid cancer papillary & 50 & 47 \\
\hline & Thyroid cancer folliculary & 49 & 45 \\
\hline & Thyroid cancer medullary & 50 & 39 \\
\hline & Adrenal gland adenoma & 50 & 40 \\
\hline & Adrenal gland carcinoma & 26 & 26 \\
\hline & Phaeochromocytoma & 50 & 49 \\
\hline & Neuroendocrine tumor (NET) & 50 & 39 \\
\hline \multirow[t]{3}{*}{ Lymphatic system } & Hodgkin's-lymphoma & 45 & 32 \\
\hline & Non Hodgkin's-lymphoma & 48 & 39 \\
\hline & Thymoma & 29 & 21 \\
\hline \multirow[t]{6}{*}{ Soft tissue } & Granular cell tumor & 30 & 24 \\
\hline & Giant cell tumor of the tendon sheat & 45 & 43 \\
\hline & Leiomyoma & 50 & 41 \\
\hline & Leiomyosarcoma & 49 & 39 \\
\hline & Liposarcoma & 49 & 37 \\
\hline & Angiosarcoma & 32 & 25 \\
\hline Bone & Chondrosarcoma & 25 & 9 \\
\hline
\end{tabular}

brightfield immunohistochemistry contributes to this problem. The selected experimental procedure defines an expression range below of which all staining will be "negative" and above of which all staining results will be "strongly positive". If an immunostaining results in "dark brown" tissue elements, a tenfold higher concentration of the protein of interest will no longer lead to a discernibly stronger staining. To minimize the risk that our experimental procedure will result in particularly good or bad data just because we were lucky (or not) to select a suitable protocol we performed the prostate cancer prognosis study by using two different antibody concentrations differing by a factor of 8 .

Overall these data show that the PSA expression level in prostate cancer cells is one of the strongest prognostic features in this tumor entity. This is not only demonstrated by the independent prognostic value of PSA staining in several models but also by its strong prognostic impact in PTEN deleted cancers. PTEN deletion is another highly prognostic feature, which has recently been recommended for measurement in routine praxis by several authors [19-22]. Most prognostic 
biomarkers lose their prognostic impact in the subgroup of PTEN deleted cancers which already are characterized by a poor prognosis $[23,24]$. The reason for higher tumor aggressiveness in cancers with reduced PSA expression is unclear. Some authors have suggested a tumor protective role of PSA. For example, Heidtmann et al. showed that PSA exerts antiangiogenic properties by converting Lys-plasminogen to biologically active angiostatin-like fragments [25]. Gkika et al. found that PSA reduces motility of PC-3 prostate cancer cells through stimulation of a particular ion channel at the plasma membrane [26]. Bindukumar et al. reported that PSA treatment modulated the expression of growth factors and suppressed the growth of prostate tumor xenografts in mice [27]. However, PSA production may be one of the most important functions of normal prostate glandular cells. One can thus speculate, that a measurable deficiency in this function might represent a subtle sign of cellular dedifferentiation. Normal prostatic glands exhibit a particular strong PSA staining at the apical cell border. That a loss of this physiological apical predominance of PSA staining is directly linked to poor prognosis, irrespective of the perceived overall staining intensity, is consistent with altered PSA representing "dedifferentiation".

The successful analysis of more than 12,000 prostate cancers revealed that even in case of undifferentiated (Gleason $\geq 8$ ) or castration resistant disease, more than $99 \%$ of prostate cancers expressed PSA at a level that was detectable at the higher antibody concentration. The $0.04 \%$ PSA negative Gleason $\leq 3+4=7$ cancers are most likely due to pre-analytical tissue damage for example caused by insufficient or prolonged formalin fixation. That small cell neuroendocrine cancers were mostly PSA negative was expected based on earlier literature [28-31]. It is of note, however, that 3 of 15 small cell carcinomas significantly expressed PSA. This demonstrates that PSA immunohistochemistry can help to identify the prostatic origin in a fraction of small cell carcinomas. The analysis of more than 2,800 non prostatic tumors showed that a positive PSA immunostaining is not completely prostatespecific. It is well known, however, that cancers can ectopically express all kinds of proteins [32]. Ectopic PSA production is thus not completely surprising. Several earlier studies have reported PSA immunostaining in considerable fractions of extraprostatic normal and neoplastic tissues. PSA expression was for example found in $9 \%-60 \%$ breast cancers [33-38], in 6 of 11 pleomorphic adenomas of the salivary gland and in one case of salivary duct carcinoma [39, 40], in all 56 cases of normal salivary gland [41], in $100 \%$ of 62 samples obtained from normal pancreas and normal salivary glands, pleomorphic adenoma, adenocarcinoma and Warthin's tumor [42], in individual cases of paraurethral adenocarcinoma [43-47] and urinary bladder cancer [48] as well as in 22 of $40(55 \%)$ of malignant melanomas [49]. Our comprehensive investigation of non-prostatic tumors for PSA expression does not provide evidence for a significant specificity problem of PSA immunohistochemistry. PSA immunostaining is rare and typically weak in extraprostatic tumors. The only extra-prostatic cancer with PSA positivity at 1:800 was a gynecological tumor. A case report on a PSA-positive endometroid ovarian cancer can also be found in the literature [50]. That a dilution of 1:800 can increase the specificity of this diagnostic test without losing significant sensitivity is valuable also with respect to economic considerations, with is a major concern in many laboratory institutions nowadays.

In summary, the comparison of two immunohistochemical protocols identifies the high antibody concentration as a suitable diagnostic approach resulting in a specificity of $99.9 \%$, an overall sensitivity of $99.7 \%$ and a sensitivity in more demanding histologies (Gleason $\geq 8$ ) of $98.7 \%$. The data also identify PSA expression as a striking prognostic parameter. The equally strong prognostic impact of PSA measurement at two different antibody concentrations suggest that the prognostically relevant expression range of PSA is very broad. PSA expression quantification over a broader range - for example by using fluorescence - might result in even better prognostic information.

\section{MATERIALS AND METHODS}

\section{Prostate cancer prognosis study}

The prostate cancer prognosis TMA contained one sample each from 17,747 patients undergoing surgery between 1992 and 2015 at the Department of Urology and the Martini Clinics at the University Medical Center Hamburg-Eppendorf. All prostate specimens were analyzed according to a standard procedure, including a complete embedding of the entire prostate for histological analysis [11]. Follow-up data were available for a total of 14,667 patients with a median follow-up of 48 months (range: 1 to 276 months). Histo-pathological and clinical data are summarized in Table 4. The molecular database attached to this TMA contained results on ERG expression [12], ERG break apart FISH analysis [13] and deletion status of 10q23 (PTEN). ERG protein expression from 5,515 and ERG rearrangement analysis by fluorescence in situ hybridization (FISH) from 8,134 tumors [13, 14] and 10q23 (PTEN) deletion status from 5,158 tumors [15].

\section{Normal tissue, advanced prostate cancer and multitumor TMA}

The normal tissue TMA was composed of 8 samples each of 76 different normal tissue types (608 samples on one slide). Each sample was derived from a different donor. Our multi tumor TMA contained 6-50 (total: 3,442) samples each from 82 different human tumor types and subtypes [16] distributed among 8 different TMA blocks. The exact composition of the normal and multi tumor TMAs is given in the results section. To enrich for prostate 
Table 4: Composition of the prostate prognosis tissue microarray

\begin{tabular}{|c|c|c|}
\hline & \multicolumn{2}{|c|}{ No. of patients (\%) } \\
\hline & Study cohort on TMA & Biochemical relapse among categories \\
\hline \multicolumn{3}{|c|}{$(n=17,747)$} \\
\hline \multicolumn{3}{|c|}{ Follow-up (mo) } \\
\hline$n$ & $14667(82.6 \%)$ & $3612(24.6 \%)$ \\
\hline Mean & 56.3 & - \\
\hline Median & 48 & - \\
\hline \multicolumn{3}{|l|}{ Age $(y)$} \\
\hline$\leq 50$ & $433(2.4 \%)$ & $66(15.2 \%)$ \\
\hline $51-59$ & $4341(24.5 \%)$ & $839(19.3 \%)$ \\
\hline $60-69$ & $9977(56.4 \%)$ & $2073(20.8 \%)$ \\
\hline$\geq 70$ & $2936(16.6 \%)$ & $634(21.6 \%)$ \\
\hline \multicolumn{3}{|c|}{ Pretreatment PSA (ng/ml) } \\
\hline$<4$ & $2225(12.6 \%)$ & $313(14.1 \%)$ \\
\hline $4-10$ & $10520(59.6 \%)$ & $1696(16.1 \%)$ \\
\hline $10-20$ & $3662(20.8 \%)$ & $1043(28.5 \%)$ \\
\hline$>20$ & $1231(7 \%)$ & $545(44.3 \%)$ \\
\hline \multicolumn{3}{|c|}{ pT stage (AJCC 2002) } \\
\hline pT2 & $11518(65.2 \%)$ & $1212(10.5 \%)$ \\
\hline pT3a & $3842(21.7 \%)$ & $1121(29.2 \%)$ \\
\hline pT3b & $2233(12.6 \%)$ & $1213(54.3 \%)$ \\
\hline pT4 & $85(0.5 \%)$ & $63(74.1 \%)$ \\
\hline \multicolumn{3}{|c|}{ Gleason grade } \\
\hline$\leq 3+3$ & $3570(18.1 \%)$ & $264(7.4 \%)$ \\
\hline $3+4$ & $9336(47.4 \%)$ & $1436(15.4 \%)$ \\
\hline $3+4$ Tert. 5 & $1697(8.6 \%)$ & $165(9.7 \%)$ \\
\hline $4+3$ & $2903(14.7 \%)$ & $683(23.5 \%)$ \\
\hline $4+3$ Tert. 5 & $1187(6 \%)$ & $487(41 \%)$ \\
\hline$\geq 4+4$ & $999(5.1 \%)$ & $531(53.2 \%)$ \\
\hline \multicolumn{3}{|l|}{ pN stage } \\
\hline pNo & $10636(89.4 \%)$ & $2243(21.1 \%)$ \\
\hline $\mathrm{pN}+$ & $1255(10.6 \%)$ & $700(55.8 \%)$ \\
\hline \multicolumn{3}{|c|}{ Surgical margin } \\
\hline Negative & $14297(80.8 \%)$ & $2307(16.1 \%)$ \\
\hline Positive & $3388(19.2 \%)$ & $1304(38.5 \%)$ \\
\hline
\end{tabular}

NOTE: Numbers do not always add up to 17,747 in the different categories because of cases with missing data.

Abbreviation: AJCC, American Joint Committee on Cancer.

cancers that are most likely to have low PSA expression, an additional "advanced prostate cancer" TMA contained tissues from 316 patients who underwent transurethral resection for recurrent and advanced prostate cancer. The cohort included 55 patients that were known to be castration resistant and 257 patients for which the cancers sensitivity to hormone withdrawal was unknown. For all TMA sets, tissue cylinders with a diameter of $0.6 \mathrm{~mm}$ were punched from representative tumor or normal areas of each tissue block and brought into a recipient paraffin block. All tumor samples were obtained from the archives of the Institute of Pathology of the University Medical Center Hamburg Eppendorf. The use of archived diagnostic left-over tissues for manufacturing of TMAs and their analysis for research purposes has been approved by local laws (HmbKHG, $\S 12,1$ ) and by the local ethics committee (Ethics 
commission Hamburg, WF-049/09). All work has been carried out in compliance with the Helsinki Declaration.

\section{Immunohistochemistry (IHC)}

Freshly cut TMA sections were immunostained on one day and in one experiment. The mouse monoclonal PSA antibody (Dianova DIA-PSA, clone HAM18) was applied at 1:100 and 1:800. Slides were deparaffinized and exposed to heat-induced antigen retrieval for 15 minutes at $98^{\circ} \mathrm{C}$ in pH9.0 target retrieval solution (Agilent, Santa Clara, CA, USA) in a PT Link pre-treatment module (Agilent) and stained in an Autostainer Link 48 device (Agilent). Protocol steps include 5 min peroxidase blocking (Agilent REAL), 20 min of primary antibody incubation at room temperature and visualization of the bound antibody using the EnVision Flex Kit (Agilent) according to the manufacturer's directions. Staining was typically homogenous in the analyzed tissue samples and staining intensity of all cases was semiquantitatively assessed in four categories: negative, weak, moderate, and strong.

\section{Statistics}

Statistical calculations were performed with JMP 11.0.0 software (SAS Institute Inc., NC, USA). Contingency tables and the chi ${ }^{2}$-test were performed to search for associations between molecular parameters and tumor phenotype. Survival curves were calculated according to Kaplan-Meier. The Log-Rank test was applied to detect significant survival differences between groups. Cox proportional hazards regression analysis was performed to test the statistical independence and significance between pathological, molecular and clinical variables by analyzing 4 different scenarios (Table 1). Scenario 1 evaluated all postoperatively available parameters including pathological tumor stage, pathological lymph node status $(\mathrm{pN})$, surgical margin status, preoperative serum PSA value and pathological Gleason grade obtained after the morphological evaluation of the entire resected prostate. In scenario 2, all postoperatively were used but nodal status was excluded as this parameter was often lacking, preferentially in low grade cancers. The scenarios 3 and 4 modeled the preoperative situation as much as possible and included preoperative PSA and clinical tumor stage (cT stage). The scenarios 3 and 4 differed in the Gleason grade, which was either obtained on the prostatectomy specimen (scenario 3 ) or reflected the preoperative Gleason grade defined on the original biopsy by hundreds of different pathologists.

\section{Author contributions}

AML, AH, EB, SS, TSC and GS constructed the tissue microarrays. TS, DP, AG, HHe, HHu, JRI provided clinical data. SB, AP, GSo, SM analyzed the immunostainings. MK, GM-F, CM-K, MW, RS and GS contributed to the antibody generation and/or validation. $\mathrm{CH}-\mathrm{M}$ and RS preformed the statistical analyses. WW, GS and RS planned the study and drafted the manuscript. All authors contributed to the final manuscript.

\section{ACKNOWLEDGMENTS}

We are grateful to Ilknur Aynur, Ferdag Guen, Felisa Fürstenberger, Maren Eisenberg, Inge Brandt and Sünje Seekamp for excellent technical support.

\section{CONFLICTS OF INTEREST}

G. Sauter and R. Simon have developed the antiPSA antibody (DIA-PSA, clone HAM18) in cooperation with Dianova GmbH, Warburgstraße 45, 20354 Hamburg.

\section{REFERENCES}

1. Siegel RL, Miller KD, Jemal A. Cancer statistics, 2019. CA Cancer J Clin. 2019; 69:7-34. https://doi.org/10.3322/ caac. 21551. [PubMed]

2. Malm J, Lilja H. Biochemistry of prostate specific antigen, PSA. Scand J Clin Lab Invest Suppl. 1995; 221:15-22. https://doi.org/10.3109/00365519509090559. [PubMed]

3. Lilja H. A kallikrein-like serine protease in prostatic fluid cleaves the predominant seminal vesicle protein. J Clin Invest. 1985; 76:1899-1903. https://doi.org/10.1172/ JCI112185. [PubMed]

4. Babaian RJ, Troncoso P, Steelhammer LC, Lloreta-Trull J, Ramirez EI. Tumor volume and prostate specific antigen: implications for early detection and defining a window of curability. J Urol. 1995; 154:1808-1812. https://doi. org/10.1016/S0022-5347(01)66790-9. [PubMed]

5. Epstein JI, Egevad L, Humphrey PA, Montironi R. Members of the IIiDUPG. Best practices recommendations in the application of immunohistochemistry in the prostate: report from the International Society of Urologic Pathology consensus conference. Am J Surg Pathol. 2014; 38:e6-e19. https://doi.org/10.1097/PAS.0000000000000238. [PubMed]

6. Goldstein NS. Immunophenotypic characterization of 225 prostate adenocarcinomas with intermediate or high Gleason scores. Am J Clin Pathol. 2002; 117:471-477. https://doi.org/10.1309/G6PR-Y774-X738-FG2K. [PubMed]

7. Abrahamsson PA, Lilja H, Falkmer S, Wadstrom LB. Immunohistochemical distribution of the three predominant secretory proteins in the parenchyma of hyperplastic and neoplastic prostate glands. Prostate. 1988; 12:39-46. https:// doi.org/10.1002/pros.2990120106. [PubMed]

8. Gallee MP, Visser-de Jong E, van der Korput JA, van der Kwast TH, ten Kate FJ, Schroeder FH, Trapman J. Variation of prostate-specific antigen expression in different tumour growth patterns present in prostatectomy specimens. Urol Res. 1990; 18:181-187. https://doi.org/10.1007/ BF00295844. [PubMed] 
9. Varma M, Morgan M, Jasani B, Tamboli P, Amin MB. Polyclonal anti-PSA is more sensitive but less specific than monoclonal anti-PSA: Implications for diagnostic prostatic pathology. Am J Clin Pathol. 2002; 118:202-207. https:// doi.org/10.1309/BGWQ-P26T-7TR6-VGT3. [PubMed]

10. Erbersdobler A, Isbarn H, Steiner I, Schlomm T, Chun F, Mirlacher M, Sauter G. Predictive value of prostatespecific antigen expression in prostate cancer: a tissue microarray study. Urology. 2009; 74:1169-1173. https:// doi.org/10.1016/j.urology.2009.02.061. [PubMed]

11. Schlomm T, Iwers L, Kirstein P, Jessen B, Kollermann J, Minner S, Passow-Drolet A, Mirlacher M, Milde-Langosch K, Graefen M, Haese A, Steuber T, Simon R, et al. Clinical significance of $\mathrm{p} 53$ alterations in surgically treated prostate cancers. Mod Pathol. 2008; 21:1371-1378. https://doi. org/10.1038/modpathol.2008.104. [PubMed]

12. Weischenfeldt J, Simon R, Feuerbach L, Schlangen K, Weichenhan D, Minner S, Wuttig D, Warnatz HJ, Stehr H, Rausch T, Jager N, Gu L, Bogatyrova O, et al. Integrative genomic analyses reveal an androgen-driven somatic alteration landscape in early-onset prostate cancer. Cancer Cell. 2013; 23:159-170. https://doi.org/10.1016/j. ccr.2013.01.002. [PubMed]

13. Minner S, Enodien M, Sirma H, Luebke AM, Krohn A, Mayer PS, Simon R, Tennstedt P, Muller J, Scholz L, Brase JC, Liu AY, Schluter H, et al. ERG status is unrelated to PSA recurrence in radically operated prostate cancer in the absence of antihormonal therapy. Clin Cancer Res. 2011; 17:5878-5888. https://doi.org/10.1158/1078-0432.CCR-111251. [PubMed]

14. Minner S, Wittmer C, Graefen M, Salomon G, Steuber T, Haese A, Huland H, Bokemeyer C, Yekebas E, Dierlamm J, Balabanov S, Kilic E, Wilczak W, et al. High level PSMA expression is associated with early PSA recurrence in surgically treated prostate cancer. Prostate. 2011; 71:281288. https://doi.org/10.1002/pros.21241. [PubMed]

15. Krohn A, Diedler T, Burkhardt L, Mayer PS, De Silva C, Meyer-Kornblum M, Kotschau D, Tennstedt P, Huang J, Gerhauser C, Mader M, Kurtz S, Sirma H, et al. Genomic deletion of PTEN is associated with tumor progression and early PSA recurrence in ERG fusion-positive and fusionnegative prostate cancer. Am J Pathol. 2012; 181:401-412. https://doi.org/10.1016/j.ajpath.2012.04.026. [PubMed]

16. Rawnaq T, Quaas A, Zander H, Gros SJ, Reichelt U, Blessmann M, Wilzcak W, Schachner M, Sauter G, Izbicki JR, Kaifi JT. L1 is highly expressed in tumors of the nervous system: a study of over 8000 human tissues. J Surg Res. 2012; 173:314-9. https://doi.org/10.1016/j. jss.2010.10.029. [PubMed]

17. Person F, Wilczak W, Hube-Magg C, Burdelski C, MollerKoop C, Simon R, Noriega M, Sauter G, Steurer S, BurdakRothkamm S, Jacobsen F. Prevalence of $\beta$ III-tubulin (TUBB3) expression in human normal tissues and cancers. Tumour Biol. 2017; 39:1010428317712166. https://doi. org/10.1177/1010428317712166. [PubMed]
18. Burdelski C, Jakani-Karimi N, Jacobsen F, Moller-Koop C, Minner S, Simon R, Sauter G, Steurer S, Clauditz TS, Wilczak W. IMP3 overexpression occurs in various important cancer types and is linked to aggressive tumor features: A tissue microarray study on 8,877 human cancers and normal tissues. Oncol Rep. 2018; 39:3-12. https://doi. org/10.3892/or.2017.6072. [PubMed]

19. Baak JP, Van Diermen B, Steinbakk A, Janssen E, Skaland I, Mutter GL, Fiane B, Lovslett K. Lack of PTEN expression in endometrial intraepithelial neoplasia is correlated with cancer progression. Hum Pathol. 2005; 36:555-561. https:// doi.org/10.1016/j.humpath.2005.02.018. [PubMed]

20. Lotan TL, Gurel B, Sutcliffe S, Esopi D, Liu W, Xu J, Hicks JL, Park BH, Humphreys E, Partin AW, Han M, Netto GJ, Isaacs $\mathrm{WB}$, et al. PTEN protein loss by immunostaining: analytic validation and prognostic indicator for a high risk surgical cohort of prostate cancer patients. Clin Cancer Res. 2011; 17:6563-6573. https://doi.org/10.1158/1078-0432. CCR-11-1244. [PubMed]

21. Sabha N, Knobbe CB, Maganti M, Al Omar S, Bernstein M, Cairns R, Cako B, von Deimling A, Capper D, Mak TW, Kiehl TR, Carvalho P, Garrett E, et al. Analysis of IDH mutation, 1p/19q deletion, and PTEN loss delineates prognosis in clinical low-grade diffuse gliomas. Neuro Oncol. 2014; 16:914-923. https://doi.org/10.1093/neuonc/ not299. [PubMed]

22. Carvalho KC, Maia BM, Omae SV, Rocha AA, Covizzi LP, Vassallo J, Rocha RM, Soares FA. Best practice for PTEN gene and protein assessment in anatomic pathology. Acta Histochem. 2014; 116:25-31. https://doi.org/10.1016/j. acthis.2013.04.013. [PubMed]

23. Burdelski C, Fitzner M, Hube-Magg C, Kluth M, Heumann A, Simon R, Krech T, Clauditz T, Buscheck F, Steurer S, Wittmer C, Hinsch A, Luebke AM, et al. Overexpression of the A Disintegrin and Metalloproteinase ADAM15 is linked to a Small but Highly Aggressive Subset of Prostate Cancers. Neoplasia. 2017; 19:279-287. https://doi. org/10.1016/j.neo.2017.01.005. [ubMed]

24. Burdelski C, Menan D, Tsourlakis MC, Kluth M, HubeMagg C, Melling N, Minner S, Koop C, Graefen M, Heinzer H, Wittmer C, Sauter G, Simon R, et al. The prognostic value of SUMO1/Sentrin specific peptidase 1 (SENP1) in prostate cancer is limited to ERG-fusion positive tumors lacking PTEN deletion. BMC Cancer. 2015; 15:538. https://doi.org/10.1186/s12885-015-1555-8. [PubMed]

25. Heidtmann HH, Nettelbeck DM, Mingels A, Jager R, Welker HG, Kontermann RE. Generation of angiostatin-like fragments from plasminogen by prostate-specific antigen. Br J Cancer. 1999; 81:1269-1273. https://doi.org/10.1038/ sj.bjc.6692167. [PubMed]

26. Gkika D, Flourakis M, Lemonnier L, Prevarskaya N. PSA reduces prostate cancer cell motility by stimulating TRPM8 activity and plasma membrane expression. Oncogene. 
2010; 29:4611-4616. https://doi.org/10.1038/onc.2010.210. [PubMed]

27. Bindukumar B, Schwartz SA, Nair MP, Aalinkeel R, Kawinski E, Chadha KC. Prostate-specific antigen modulates the expression of genes involved in prostate tumor growth. Neoplasia. 2005; 7:241-252. https://doi. org/10.1593/neo.04529. [PubMed]

28. Schron DS, Gipson T, Mendelsohn G. The histogenesis of small cell carcinoma of the prostate. An immunohistochemical study. Cancer. 1984; 53:2478-2480. https://doi. org/10.1002/1097-0142(19840601)53:11<2478::AIDCNCR2820531119>3.0.CO;2-Q. [PubMed]

29. Okada H, Gotoh A, Ogawa T, Arakawa S, Ohbayashi C, Kamidono S. Two cases of small cell carcinoma of the prostate. Scand J Urol Nephrol. 1996; 30:503-508. https:// doi.org/10.3109/00365599609182334. [PubMed]

30. Yao JL, Madeb R, Bourne P, Lei J, Yang X, Tickoo S, Liu Z, Tan D, Cheng L, Hatem F, Huang J, Anthony di Sant'Agnese P. Small cell carcinoma of the prostate: an immunohistochemical study. Am J Surg Pathol. 2006; 30:705-712. https://doi.org/10.1097/00000478-20060600000005. [PubMed]

31. Wang W, Epstein JI. Small cell carcinoma of the prostate. A morphologic and immunohistochemical study of 95 cases. Am J Surg Pathol. 2008; 32:65-71. https://doi.org/10.1097/ PAS.0b013e318058a96b. [PubMed]

32. Bradner JE, Hnisz D, Young RA. Transcriptional Addiction in Cancer. Cell. 2017; 168:629-643. https://doi. org/10.1016/j.cell.2016.12.013. [PubMed]

33. Poh BH, Jayaram G, Sthaneshwar P, Yip CH. Prostatespecific antigen in breast disease. Malays J Pathol. 2008; 30:43-51. [PubMed]

34. Alanen KA, Kuopio T, Collan YU, Kronqvist P, Juntti L, Nevalainen TJ. Immunohistochemical labelling for prostate-specific antigen in breast carcinomas. Breast Cancer Res Treat. 1999; 56:169-176. https://doi. org/10.1023/A:1006210627219. [PubMed]

35. Heyl W, Wolff JM, Biesterfeld S, Schroder W, Zitzelsberger D, Jakse G, Rath W. Immunohistochemical analysis of prostate-specific antigen does not correlate to other prognostic factors in breast cancer. Anticancer Res. 1999; 19:2563-2565. [PubMed]

36. Miller MK, Unger PD, Bleiweiss IJ. Immunohistochemical analysis of prostate specific antigen in breast cancer. Breast Cancer Res Treat. 2001; 68:111-116. https://doi. org/10.1023/A:1011959127928. [PubMed]

37. Ilvan S, Celik V, Cetinaslan I, Calay Z, Ferahman M. Immunohistochemical analysis of prostate-specific antigen in female breast cancer. J BUON. 2004; 9:183-186. [PubMed]

38. Narita D, Cimpean AM, Anghel A, Raica M. Prostatespecific antigen value as a marker in breast cancer. Neoplasma. 2006; 53:161-167. [PubMed]

39. van Krieken JH. Prostate marker immunoreactivity in salivary gland neoplasms. A rare pitfall in immunohistochemistry. Am J Surg Pathol. 1993;
17:410-414. https://doi.org/10.1097/00000478-19930400000012. [PubMed]

40. James GK, Pudek M, Berean KW, Diamandis EP, Archibald BL. Salivary duct carcinoma secreting prostate-specific antigen. Am J Clin Pathol. 1996; 106:242-247. https://doi. org/10.1093/ajcp/106.2.242. [PubMed]

41. Tazawa K, Kurihara Y, Kamoshida S, Tsukada K, Tsutsumi Y. Localization of prostate-specific antigen-like immunoreactivity in human salivary gland and salivary gland tumors. Pathol Int. 1999; 49:500-505. https://doi. org/10.1046/j.1440-1827.1999.00900.x. [PubMed]

42. Elgamal AA, Ectors NL, Sunardhi-Widyaputra S, Van Poppel HP, Van Damme BJ, Baert LV. Detection of prostate specific antigen in pancreas and salivary glands: a potential impact on prostate cancer overestimation. $\mathrm{J}$ Urol. 1996; 156:464-468. https://doi.org/10.1016/S00225347(01)65883-X. [PubMed]

43. Svanholm H, Andersen OP, Rohl H. Tumour of female paraurethral duct. Immunohistochemical similarity with prostatic carcinoma. Virchows Arch A Pathol Anat Histopathol. 1987; 411:395-398. https://doi.org/10.1007/ BF00713386. [PubMed]

44. Spencer JR, Brodin AG, Ignatoff JM. Clear cell adenocarcinoma of the urethra: evidence for origin within paraurethral ducts. J Urol. 1990; 143:122-125. https://doi. org/10.1016/S0022-5347(17)39887-7. [PubMed]

45. Zaviacic M, Sidlo J, Borovsky M. Prostate specific antigen and prostate specific acid phosphatase in adenocarcinoma of Skene's paraurethral glands and ducts. Virchows Arch A Pathol Anat Histopathol. 1993; 423:503-505. https://doi. org/10.1007/BF01606542. [PubMed]

46. Ebisuno S, Miyai M, Nagareda T. Clear cell adenocarcinoma of the female urethra showing positive staining with antibodies to prostate-specific antigen and prostatic acid phosphatase. Urology. 1995; 45:682-685. https://doi. org/10.1016/S0090-4295(99)80066-1. [PubMed]

47. Sloboda J, Zaviacic M, Jakubovsky J, Hammar E, Johnsen J. Metastasizing adenocarcinoma of the female prostate (Skene's paraurethral glands). Histological and immunohistochemical prostate markers studies and first ultrastructural observation. Pathol Res Pract. 1998; 194:129-136. https://doi.org/10.1016/ S0344-0338(98)80080-0. [PubMed]

48. Grignon DJ, Ro JY, Ayala AG, Johnson DE, Ordonez NG. Primary adenocarcinoma of the urinary bladder. A clinicopathologic analysis of 72 cases. Cancer. 1991; 67:2165-2172. https:// doi.org/10.1002/1097-0142(19910415)67:8<2165::AIDCNCR2820670827>3.0.CO;2-M. [PubMed]

49. Bodey B, Bodey B Jr, Kaiser HE. Immunocytochemical detection of prostate specific antigen expression in human primary and metastatic melanomas. Anticancer Res. 1997; 17:2343-2346. [PubMed]

50. Yu H, Diamandis EP, Levesque M, Asa SL, Monne M, Croce CM. Expression of the prostate-specific antigen gene by a primary ovarian carcinoma. Cancer Res. 1995; 55:1603-1606. [PubMed] 